\title{
O maior "pelego" do mundo? Fidel Velázquez e o sindicalismo oficial no México pós-revolucionário
}

\author{
The world's greatest "pelego"? Fidel Velázquez \\ and the official unionism in post-revolutionary Mexico
}

Alexandre Fortes

\section{Introdução}

Este artigo resulta de um projeto que examina os modos como o foco na história oral, assim como em livros de memórias, biografias, discursos e declarações de sindicalistas, contribui para possibilitar um novo olhar sobre a expe-

Alexandre Fortes é professor do Programa de Pós-Graduação em História da Universidade Federal Rural do Rio de Janeiro (UFRRJ), Brasil (alexfortes@globo.com).

Artigo recebido em 29 de junho de 2009 e aprovado para publicação em 9 de setembro de 2009.

Nota do autor: Este artigo resulta do projeto de pesquisa Revendo a Relação entre Movimento Operário e Estado na América Latina: O Sindicalismo Classista no México, Argentina e Brasil, com apoio do Edital de Ciências Humanas 2007 do CNPq e do Programa Primeiros Projetos da Faperj. Uma versão preliminar com o título The Paradoxes of Populism in the Voices of Unionists: Listening to "Pelegos" and "Charros" foi apresentada na conferência Workers, the Nation-State, and Beyond: The Newberry Conference on Labor History Across the Americas, ocorrida em setembro de 2008 em Chicago e organizada pela revista Labor: Studies in Working-Class History of the Americas em associação com a Labor and Working-Class History Association (LAWCHA).

Est. Hist., Rio de Faneiro, vol. 22, n. 44, p. 459-478, julho-dezembro de 2009. 


\section{Alexandre Fortes}

riência dos trabalhadores sob regimes políticos latino-americanos tradicionalmente denominados "populistas". 1

Consideramos que, como as pesquisas têm demonstrado nas últimas décadas, a fim de alcançar uma melhor compreensão da vida sindical sob o "populismo", temos que prestar mais atenção às vozes de todos os tipos de trabalhadores e de sindicalistas, mesmo aqueles que, no Brasil e no México, foram - um tanto quanto imprecisamente - classificados como "pelegos" ou "charros" (o termo mexicano equivalente ao nosso "pelego").

Avaliamos ainda que a produção recente sobre a história do trabalho na América Latina, na qual o uso desse tipo de fonte tem desempenhado um papel relevante, permite uma compreensão mais acurada das similaridades entre os diferentes países naquele momento histórico, assim como de suas peculiaridades nacionais. Mas pensamos que o potencial comparativo contido nesses trabalhos raramente tem sido realizado.

A proposta aqui é examinar, com base na bibliografia e em fontes publicadas, a trajetória de Fidel Velázquez Sanchez como líder supremo da Confederación de Trabajadores de México (CTM) e o modo como ele justificou suas escolhas políticas em seus discursos e declarações. Vale ressaltar que nosso primeiro contato com esse intrigante personagem histórico se deu quando desempenhávamos funções de assessoria sindical no final dos anos 1980 e ouvimos de um militante mais experiente o comentário de que "o maior pelego do mundo" era um mexicano, numa referência provável tanto ao poder de Velázquez sobre o sindicalismo daquele país quanto à longa duração de seu "reinado".

Conforme apontaremos brevemente ao final, a partir dessa reflexão identificamos elementos que abrem a possibilidade de análises comparativas com os resultados de nossos trabalhos anteriores sobre as diferenças de concepções e práticas sindicais entre líderes que atuaram no Brasil no período 1930-1964 e que foram em muitas ocasiões classificados indiferenciadamente como "pelegos" por seus adversários políticos. Acreditamos que a comparação entre trajetórias vividas nesses dois contextos nacionais, cujo pleno desenvolvimento vai além dos limites do possível no âmbito deste artigo, podem enriquecer o nosso conhecimento sobre a relação entre o "populismo" e a classe trabalhadora latino-americana.

\section{Os sindicalistas e o "populismo"}

Nas últimas décadas, os estudos sobre o tema "trabalhadores e populismo" têm dedicado uma atenção maior às memórias e trajetórias de militantes e líderes sindicais. No Brasil, grande parte dos trabalhos que integraram o movi- 
mento de renovação na abordagem historiográfica sobre o período entre 1930 e 1964 fez extenso uso de fontes orais, aproveitando as últimas oportunidades para registrar as experiências daqueles que viveram a Era Vargas (Costa, 1995; Silva, 1995; Mattos, 1998; Santana, 2001; Silva, 2003; Negro, 2004). Em um dos casos mais relevantes, Marcos Andreotti, o principal líder dos metalúrgicos do ABC paulista antes do golpe de 1964, foi resgatado do anonimato, e suas entrevistas tiveram um papel fundamental nas análises inovadoras de John French (1995) sobre o período.

$\mathrm{Na}$ Argentina, muitos autores utilizaram as memórias publicadas do líder dos trabalhadores de frigoríficos, Cipriano Reyes (1973), inicialmente um importante aliado e mais tarde um inimigo político de Perón, assim como as do líder dos telefônicos, Luis Gay (Gay e Torre, 1999), ambos fundadores do Partido Laborista, como importante ferramenta para alcançar uma compreensão mais nuançada das origens do peronismo (Portantiero e Murmis, 1971; Horowitz, 1983; Torre, 1990), uma inflexão cujos sinais podiam ser percebidos muitos anos antes que um processo similar começasse a ocorrer no Brasil. Daniel James, após produzir um trabalho fundamental sobre a relação entre os trabalhadores e o peronismo (James, 1988), concentrou-se nas transcrições de suas entrevistas com a organizadora de base nos frigoríficos da cidade de Berisso, Doña María Roldán, analisando as contradições de um movimento político que criou novas oportunidades para a militância de importantes setores femininos da classe operária, mas, ao mesmo tempo, reafirmava visões tradicionais sobre o papel da mulher na sociedade (James, 2000). A história oral também foi uma importante fonte para a reconstrução detalhada da história social e política de Berisso feita por Mirta Lobato em La vida en las fábricas (Lobato, 2001).

No México, um país no qual as estruturas de poder geradas pelo processo revolucionário vieram a conferir a alguns sindicalistas posições de poder sem paralelo, a análise de trajetórias como as de Fidel Velázquez Sánchez, o leiteiro que se tornou o líder inconteste da maior central sindical do país, continua a habitar uma zona indefinida entre a lenda e a história. Em um livro recente, por exemplo, um escritor mexicano declara que Velázquez era um dos cinco membros de uma sociedade secreta que tomou "as principais decisões políticas do México" por 50 anos (Velasco Piña, 2005). ${ }^{2}$ A apresentação de comunicações sobre dois outros proeminentes sindicalistas mexicanos, Vicente Lombardo Toledano e Luis Napoleón Morones, na conferência da Latin American Studies Association ocorrida em Montréal em 2007, demonstra, contudo, um interesse acadêmico crescente nos estudos biográficos como meios de repensar a relação entre o movimento operário e o Estado também naquele país. ${ }^{3}$

Tradicionalmente, os sindicalistas latino-americanos que atuavam durante o chamado "período populista" eram classificados de acordo com o seu per- 


\section{Alexandre Fortes}

tencimento ou proximidade a tendências e partidos políticos, ou então eram simplesmente identificados por meio de rótulos usados nas disputas internas do movimento operário para acusar os adversários de servir aos interesses dos empregadores e do Estado, em vez dos interesses dos trabalhadores.

No caso mexicano, o uso do termo "charro" remonta à deposição e posterior encarceramento dos líderes ferroviários Luis Gómez Z. e Valentim Campa, que ficou conhecida no folclore sindical mexicano como "Charrazo", em função de que o articulador da manobra, o secretário-geral do sindicato dos ferroviários, Jesús Díaz de Léon, nutria tamanha admiração pelos tradicionais rodeios de cavalos mexicanos ("charraria"), que costumava se vestir com os trajes típicos neles utilizados. A partir daí, "charro" passou a ser usado como um adjetivo aplicável aos dirigentes que governam despoticamente seus sindicatos, utilizando-se do apoio do governo para eliminar a oposição (Middlebrook, 1995: 135-141).

É evidente que o objetivo do uso desses termos é desqualificar o adversário, identificando-o como representante não de uma concepção política distinta, mas sim de interesses contrários aos da própria classe trabalhadora. Como os estudos sobre o movimento operário na América Latina foram, desde o início, fortemente influenciados pelas posições críticas à forma como se dava a relação entre Estado e trabalhadores sob o "sistema populista" - fossem essas críticas formuladas de uma perspectiva marxista ou liberal -, com frequência essas categorias foram naturalizadas e incorporadas à análise, pois os autores compartilhavam da aversão e desdém por aqueles a quem tais rótulos eram aplicados. No caso brasileiro, para o período pós-1930, esses termos foram às vezes substituídos nos trabalhos acadêmicos por outros, tais como "ministerialista"4 (vinculado ao Ministério do Trabalho), "colaboracionista" ou "oficialista", os quais, entretanto, continuavam a indicar que os indivíduos por eles designados não deveriam ser considerados "autênticos" sindicalistas, mas sim instrumentos a serviço dos patrões e/ou do Estado no meio operário.

O uso dessas classificações, entretanto, enseja sérios problemas. Ao contrário do que ocorre com o pertencimento a correntes político-ideológicas ou movimentos políticos, tais como comunismo, trabalhismo, peronismo, cardenismo, as denominações pejorativas mencionadas acima não costumavam ser assumidas como formas de auto-identificação de grupos ou indivíduos atuantes no movimento sindical. Fidel Velázquez, por exemplo, busca se desvencilhar do rótulo remetendo não ao sentido político que ele adquiriu, mas à sua origem nas tradições rurais mexicanas: "Como homem do campo, montei nos meus primeiros anos a cavalo, porém, nunca me vesti de charro, pois no campo não se vestem de charros. No campo se vestem com roupas de trabalho" (Prieto, 1980: 56).

É claro que as ponderações acima não implicam dizer que os fenômenos que esses termos pretendem descrever não existem. Ou seja, pode ser possível em 
alguns casos demonstrar objetivamente que determinados ocupantes de cargos sindicais tinham como único objetivo manter os trabalhadores sob controle do Estado e dos patrões. Mas quais os limites e os procedimentos razoáveis para a aplicação desse tipo de identificação? Teriam tido o "peleguismo", o "oficialismo" ou o "charrismo" uma dimensão tão ampla quanto muitas vezes se supõe? Como diferenciar essas atitudes e posicionamentos de um realismo voltado ao uso de todas as possibilidades colocadas para maximizar os ganhos dos trabalhadores sob o "populismo"?

O exame dos múltiplos fatores que explicam a emergência e o desenvolvimento de cada liderança, assim como dos meios pelos quais os próprios sindicalistas formulam suas lembranças sobre processos organizacionais e lutas, negociações e tomadas de decisões, debates políticos e ideológicos, ao lado de outros elementos recorrentes da vida interna do movimento operário, leva, necessariamente, a relativizar essas classificações.

O que a experiência concreta dos sindicalistas revela é que no espaço ambíguo, conflitivo e incerto do "sistema político populista" as definições sobre quais eram os reais interesses da classe trabalhadora e o cálculo estratégico sobre quais eram as melhores maneiras de defendê-los ocorriam de um modo muito mais complexo do que os observadores externos podem supor a posteriori. Por outro lado, ao reavaliar a atuação desses líderes sindicais pragmáticos a partir de documentos testemunhais, precisamos redobrar nossos cuidados em relação ao risco de incorporar à análise, de forma acrítica e reificada, a sua visão restritiva sobre o campo de possibilidades colocado para a ação dos trabalhadores no período.

Ao recorrermos à análise da situação mexicana em busca de elementos comparativos que possam enriquecer nossa reflexão sobre o caso brasileiro, temos que observar que o poder dos sindicalistas como atores políticos nacionais no período foi, no Brasil, infinitamente inferior. Parece paradoxal, agora que nosso país é presidido pela segunda vez consecutiva por um ex-sindicalista metalúrgico, relembrar que durante quase 50 anos não havia nele paralelo para figuras como Luís Morones, Vicente Lombardo Toledano e Fidel Velázquez Sánchez. O mesmo poderia ser dito sobre a Argentina, mencionando-se por exemplo, para momentos distintos, Cipriano Reyes e Augusto Vandor (James, 1988: 159-211). Portanto, por mais que possamos identificar similaridades nas condições colocadas para a prática sindical sob as estruturas institucionais geradas pela Revolução Mexicana e pela Era Vargas, há certos limites instransponíveis para esse exercício comparativo.

$\mathrm{O}$ que procuraremos fazer a seguir é examinar como se articulam entre si, de um lado, o contexto de emergência da incorporação do sindicalismo como um elemento estratégico de sustentação do Estado pós-revolucionário no Méxi- 


\section{Alexandre Fortes}

co e, de outro lado, a construção da imagem pública de um sindicalista que teve papel central nesse processo. Para tanto, tomaremos como base trechos de seus discursos e declarações que apresentam um balanço da militância e justificativas para as escolhas políticas que marcaram a sua trajetória. Nas nossas conclusões, faremos alguns comentários sobre como e em que medida as experiências individuais analisadas em dois contextos nacionais distintos podem enriquecer o nosso entendimento sobre a problemática do pragmatismo sindical no contexto populista.

\section{O enigma de Fidel Velázquez}

Fidel Velázquez Sánchez, nascido em 1900 e falecido em 1997, foi uma figura central do sindicalismo e da estrutura de poder no México por pelo menos 50 anos, situando-se como ator de várias conjunturas históricas decisivas, e como um dos poucos elos vivos entre momentos históricos distantes e distintos. À medida que as décadas vieram a transcorrer, Velázquez passou a encarnar uma tripla sobrevivência, sendo cada vez mais difícil discernir entre sua longevidade pessoal, sua permanência como secretário-geral da Confederación de Trabajadores Mexicanos (CTM) e a própria persistência do sindicalismo vinculado ao Estado no México. Assim, num livro baseado nos depoimentos de diversas personalidades da vida social e política mexicana sobre o personagem, muitos dos entrevistados expressam opiniões sobre "a CTM e seu líder" ou mesmo sobre "o sindicalismo mexicano e Fidel Velázquez", englobando movimento, instituição e indivíduo numa totalidade singular (Prieto, 1980: 112, 178, 213-223).

Suas opções e decisões individuais foram consideradas determinantes na explicação do rumo seguido pelos setores majoritários do sindicalismo mexicano desde meados da década de 1930. Mesmo entre seus adversários, raros foram aqueles que o trataram com menosprezo, como foi o caso de Juan Ortega Arenas, coordenador de "Unidad Obrera Independiente": "Carece de interesse falar de Fidel Velázquez, um instrumento de quinto nível, de um aparato que está fundado na Constituição e na Lei Federal do Trabalho, que é uma lei corporativa (...) copiada do Código di Lavoro de Mussolini” (apud Prieto, 1980: 67).

A avaliação sobre seu legado permaneceu polêmica mesmo após a sua morte. O Mexican Labor News and Analysis, numa edição especial dedicada ao seu obituário, destacou que ele "fez mais do que qualquer outro indivíduo para manter os trabalhadores mexicanos numa posição de subordinação ao governo mexicano, ao Partido Revolucionário Institucional (PRI) e aos empregadores" (La Botz, 1997). A versão on-line da Enciclopédia Britannica, entretanto, registra que lhe era reconhecido "o crédito de ter desempenhado um papel fundamental na 
conquista do direito legal de greve para os empregados e, de, durante os anos 1950 e 1960, ter ajudado a assegurar aumentos salariais significativos", embora acrescente que nas últimas décadas ele sofria críticas por seu apoio aos "planos governamentais de manter os salários baixos de modo a ajudar a acelerar a recuperação econômica do país". ${ }^{5}$

As pesquisas acadêmicas têm feito grandes avanços nas últimas décadas na análise do contexto que possibilitou a ascensão e permanência de Velázquez à frente da CTM e que viabilizou a linha de atuação que ele imprimiu à organização. Segundo Middlebrook, dois elementos são fundamentais para se compreender o fenômeno do sindicalismo vinculado ao Estado no México pós-revolucionário. De um lado, a Revolução Mexicana possibilitou o desenvolvimento de uma elite política que, independentemente dos seus conflitos internos, partilhou durante um longo período de "um amplo consenso sobre o valor de uma aliança estratégica com o movimento operário organizado" (Middlebrook, 1995: 30). Conforme destaca o autor, uma das pré-condições para isto é o fato de a classe política pós-revolucionária ter se originado fundamentalmente das classes médias, diferenciando-se claramente da burguesia nacional (Middlebrook, 1995: 27-28). Por outro lado, tanto a vasta predominância do setor rural como a dispersão setorial e geográfica da classe operária teriam levado a uma fraqueza no que diz respeito às condições de barganha $\mathrm{e}$, a partir daí, a um interesse numa forte presença do Estado como mediador nas relações entre capital e trabalho. Esses fatores teriam peso ainda maior no caso da CTM, baseada em sindicatos de empresa ou local de trabalho (Middlebrook, 1995: 75, 109).

Embora o sindicalismo tenha desempenhado um papel subordinado nessa aliança, o fato é que o desenvolvimento de instrumentos de controle estatal sobre as relações de trabalho foi acompanhado do reconhecimento de direitos básicos do trabalhador e da ocupação de posições na estrutura do Estado por parte de representantes operários, abrindo canais para a efetivação desses direitos. Mesmo sem controle sobre os resultados mais gerais da aliança, o sindicalismo ainda assim teria tido muitas vezes importante influência na conquista de benefícios simbólicos e materiais dela derivados (Middlebrook, 1995: 42-43). O desenvolvimento da legislação trabalhista e dos instrumentos de intervenção estatal nas relações de trabalho e nos sindicatos seriam assim uma expressão da dinâmica interativa dessa aliança, que passou por transformações significativas entre o primeiro momento em que pode ser identificado o seu estabelecimento (1917-1919) e a conjuntura em que se consagraram os seus termos definitivos (1947-1951) (Middlebrook, 1995: 46-47, 70).

As raízes do pragmatismo estariam ligadas à emergência, no final dos anos 1910, de líderes como Luís Morones, fundador da Confederación Regional Obrera Mexicana (CROM) e defensor da "flexibilidade tática" e da ideia de que o 


\section{Alexandre Fortes}

movimento operário necessitava de "menos ideias e mais organização". Assinando um pacto secreto com Álvaro Obregón, em que a central se comprometia a apoiá-lo na eleição presidencial de 1920 (em troca de posições políticas no governo, da criação de um Ministério do Trabalho e da codificação dos princípios expressos no artigo constitucional 123 em legislação trabalhista ordinária), Morones viria rapidamente $\mathrm{a}$ ascender à posição de mais poderoso dirigente operário do país no período em que o sindicalismo exerceu uma influência política sem paralelo (Middlebrook, 1995: 77). Já como Ministro do Trabalho no governo Calles, Morones entraria em conflito aberto com os sindicatos nacionais industriais que questionavam a hegemonia da CROM e posteriormente viria a cair em desgraça política ao ser acusado de envolvimento no assassinato de Obregón, após este ter se tornado o maior crítico do poder sindical excessivo e ter sido reeleito para a Presidência da República (Middlebrook, 1995: 80-81).

O balanço da experiência da CROM seria decisivo na trajetória dos dirigentes que, como Vicente Lombardo Toledano e Fidel Velázquez, participaram dessa poderosa central nos anos 1920 e posteriormente vieram a fundar a CTM. De um lado, os direitos e a influência conquistados durante o governo Calles demonstravam claramente as vantagens de uma aproximação com o governo. De outro, o impacto avassalador da queda de Morones sobre a CROM demonstrava os riscos de uma excessiva dependência do Estado e, principalmente, de uma confrontação aberta com os detentores do poder (Middlebrook, 1995: 82).

No início da década de 1930, uma conjunção de fatores criava condições propícias para uma nova experiência de unificação de uma ampla frente sindical. Enquanto o Partido Comunista Mexicano (PCM) fazia da unidade sua grande bandeira, os sindicatos industriais nacionais obtinham sucesso em articular os diversos ramos e profissões de setores estratégicos (energia elétrica, ferrovias, petróleo, minas e metalurgia). Ao mesmo tempo, Toledano liderava os setores dissidentes da CROM e outras organizações operárias e camponesas na fundação da Confederación General de Obreros y Campesinos de México (CGOCM) (Middlebrook, 1995: 84-85). Durante o governo Lázaro Cárdenas (1934-1940), o processo pós-revolucionário chegava a seu momento de maior radicalidade no que diz respeito a reformas sociais, colocando a necessidade de um movimento operário unificado como ator político nacional a contrabalançar as forças da reação. Ao mesmo tempo, Cárdenas cuidou de limitar o poder da CTM, quando apoiou a formação da Federación de Sindicatos de Trabajadores a Servicio del Estado e se opôs à sindicalização de trabalhadores rurais nas mesmas organizações dos operários (Middlebrook, 1995: 91). É nesse contexto que se localiza o conflito entre Cárdenas e Calles, aberto com o pronunciamento em que o último (autoproclamado "chefe máximo da Revolução") criticava a onda de greves em desenvolvimento no país como uma "traição nacional". 
Esta rápida contextualização histórica permite identificar as particularidades que cercam a própria criação da CTM. De um lado, resultado da luta pela unidade dos trabalhadores, de outro, consequência de um sistema político em que a mobilização real ou potencial de massas organizadas tornou-se, a partir da Revolução, um dos recursos centrais do jogo de poder.

A transformação do PRN (Partido Nacional Revolucionário, 1929-1938) em PRM (Partido da Revolução Mexicana, 1938-1946) respondeu à busca de mobilização popular por parte de Cárdenas, incluindo a reorganização do partido em setores (sindical, camponês, popular e militar). Ao mesmo tempo, essa organização setorial correspondia à política de "frente popular", respaldada pelo PCM, o que explica a ausência de maiores resistências a que a CTM viesse a se inserir no setor sindical do PRM, estabelecendo-se um sistema de "filiação indireta" dos sindicalizados ao partido, com base no qual a central viria a postular importantes posições eleitorais para seus dirigentes. Velázquez, particularmente, teve uma vaga de Senador pelo Distrito Federal praticamente assegurada para si ou para um de seus colaboradores próximos entre 1940 e 1988 (Middlebrook, 1995: 93-94, 105). Nas raras ocasiões em que o número de vagas eleitorais colocadas à disposição da CTM pelo PRM foi reduzido, como durante o governo do general Manuel Ávila Camacho (1940-1946), o situacionismo da central não impediu que Fidel fizesse duras críticas à medida (Segovia, 1986: 77).

A redução do espaço político dado à central era um claro reflexo da passagem do governo reformista de Cárdenas para o conservadorismo de Ávila Camacho, durante a Segunda Guerra Mundial. Apesar das críticas, entretanto, Velázquez endossou a substituição da política anterior de "frente popular" pela defesa da "unidade nacional" que marcava a nova conjuntura política do país, conforme pode ser claramente percebido pela análise dos seus discursos no período (Segovia, 1986: 27-135). ${ }^{6}$

Foi precisamente este o momento em que alguns dos mecanismos criados ou reforçados no período de Cárdenas a fim de fortalecer os sindicatos, como expressão da aliança baseada em um programa compartilhado entre Estado e movimento sindical, passaram a indicar muito mais uma relação de dependência do segundo em relação ao primeiro. No que diz respeito ao repasse de verbas públicas aos sindicatos, embora tenham sido feitas tentativas de manter uma arrecadação própria, as dificuldades enfrentadas foram grandes, e a tendência à dependência financeira do Estado mostrou-se irreversível (Middlebrook, 1995: 95-101). Ávila Camacho aplicou severas restrições ao direito de greve, a partir da declaração do "Estado de Guerra" em 1942, ao próprio direito de reunião. Numa conjuntura de alta inflação, essas medidas limitavam a capacidade de mobilização operária para reagir frente às perdas salariais (Middlebrook, 1995: 113-114). Foi nesse contexto que Fidel assumiu a Secretaria-Geral da CTM pela primeira vez, em 1941, substituindo Toledano. 
A ascensão de Velázquez indicava o fortalecimento do grupo de sindicalistas denominado de "cinco lobinhos", que além dele incluía Fernando Amilpa, Jesús Yurén, Luis Quintero e Adolfo Sánchez Madariaga, todos fundadores da Federación Sindical de Trabajadores del Distrito Federal (FSTDF). Rompendo com a CROM em 1929, os cinco se dedicaram, na década seguinte, à criação e fortalecimento de pequenos sindicatos, o que os diferenciava da ênfase à "grande política" característica de Toledano e lhes granjeava um substantivo e crescente apoio nas bases da CTM (Prieto, 1980: 132-136). Após assumirem o comando da central, os "lobinhos" produziram uma profunda mudança na correlação de forças, que ficou evidente na conjuntura de 1947-51, em que enfrentaram e derrotaram todos os demais grupos nela presentes na gestão de Fernando Amilpa (1947-1950) à frente da Secretaria-Geral. A combinação da transformação do PRM em Partido Revolucionário Institucional (PRI), em 1948, com a conclamação de Lombardo Toledano à formação de um novo partido (Partido Popular) levou a CTM a um novo nível de vinculação com a política oficial, prevalecendo a interpretação de que os estatutos da central obrigavam seus membros à filiação individual ao "partido da revolução". Expulsos Toledano e seus seguidores, a eles se seguiram os líderes sindicais comunistas (Segovia, 1986: 115-117; Middlebrook, 1995: 223-245).

Embora a oposição representasse setores sindicais estratégicos, como era o caso dos ferroviários (Middlebrook, 1995: 122-123), suas divisões internas somaram-se à intervenção governamental ativa para levar à sua derrota na tentativa de construção de uma central capaz de rivalizar com a CTM. No próprio episódio que deu origem ao termo "charrismo", o PCM evitou assumir uma postura mais ativa contra o processo de intervenção governamental no sindicato dos ferroviários a pretexto de uma suposta apropriação de recursos da entidade, usados na fundação da Central Única de los Trabajadores (CUT). A este episódio, seguiram-se intervenções similares nos sindicatos de petroleiros, mineiros e metalúrgicos (Middlebrook, 1995: 141-155, 383). Ao assumir a Secretaria-Geral pela segunda vez, em 1950, Fidel Velázquez controlava uma CTM institucionalizada como força majoritária do sindicalismo mexicano sem enfrentar qualquer força de oposição interna organizada.

Essa ascensão do ex-leiteiro a uma posição de tamanho poder provocou desde então a admiração tanto de seus adeptos quanto de seus críticos. Astuto para os primeiros, traiçoeiro para os segundos, o "lobinho pródigo" (Segovia, 1986) sem dúvida demonstrou enorme capacidade de manobra durante a sua trajetória política, partindo de uma posição secundária como líder setorial e local para tornar-se um mito nacional que encarnou a própria natureza das relações entre movimento operário e Estado.

Conforme já indicamos acima, de um lado, a força de Velázquez e de seu grupo vinha da sua capacidade de construir uma base sindical nacional a partir 
de federações locais e regionais que representavam a única alternativa válida para a representação sindical da maioria dos trabalhadores mexicanos, empregados em ramos marcados por enorme dispersão setorial, profissional e geográfica. Essas organizações cobriam um espectro de trabalhadores com uma diversidade muito maior do que qualquer grande sindicato industrial nacional, constituindo ao mesmo tempo uma rede de dirigentes intermediários espalhada por todo o país, que viria a se constituir em um recurso político de grande valor. Mas, além da articulação de uma base distinta, a construção do espaço político de Fidel Velázquez envolveu o desenvolvimento de um estilo de liderança peculiar, construído basicamente a partir de uma releitura da atuação dos grandes líderes sindicais com os quais conviveu no seu período formativo: Luis Morones e Vicente Lombardo Toledano.

De Morones, Fidel incorporou o pragmatismo, a valorização da organização em primeiro lugar, frente à ideologia, e a "flexibilidade tática". Por outro lado, nada seria mais estranho a Fidel Velázquez do que a figura de Morones, retratado como um ser imenso, de apetites insaciáveis, que "comia e bebia sem medida", em cuja Quinta de Tlalpan "se armavam orgias e bacanais, com mulheres levadas de teatros e escritórios do governo municipal da cidade do México" (González, 1991: 24). Essas características eram facilmente associadas à imagem de ambições políticas igualmente ilimitadas, que levaram à denúncia de sua intenção de vir a ser presidente da República, tornando-o um dos alvos mais óbvios das suspeitas que cercavam assassinato de Obregón.

Ao contrário, Velázquez caracterizou-se sempre por manter grande discrição pessoal, coroada pelo uso de ternos sóbrios e pelos enigmáticos óculos escuros, interpretados por muitos como um estratagema utilizado para ocultar as emoções de seu portador. A imagem de austeridade era cuidadosamente cultivada pelo poderoso dirigente sindical:

A aspiração de todo homem deve ser ter o necessário para viver. O que aspira a mais já sai deste marco e se converte num explorador. A mim nunca me interessou o dinheiro. Tenho minha casa, meu automóvel, vivo com o necessário, sem nenhuma ostentação ou luxo, porque não necessito de mais, absolutamente. (Prieto, 1980: $110-111)$

É notável a ausência de ataques à honestidade pessoal de Fidel entre seus críticos mais contundentes, enquanto escândalos de real ou suposta corrupção vieram a derrubar alguns dos dirigentes sindicais mexicanos mais poderosos ao longo das quase seis décadas do seu "reinado". Mesmo o autor do obituário alta- 


\section{Alexandre Fortes}

mente crítico mencionado no início desta seção é forçado a reconhecer que "Velázquez não era, como seu predecessor Luis N. Morones da CROM, dado ao consumo conspícuo e à exibição ostentatória de sua riqueza. Fidel amava o poder mais do que ele se interessava pela riqueza" (La Botz, 1997).

O cultivo da imagem sóbria, porém, pouco tem a ver com uma atitude moralista. Ao ser acusado por seu amigo Amilpa de conivência com o gangsterismo dentro da CTM em 1950, Velázquez replicou:

Amilpa, como eu e como todos, temos convivido juntos dentro desta organização com pessoas que não têm sido precisamente um modelo de honestidade. Mas nunca esteve em nossas faculdades aplicar-lhes sanção alguma enquanto os trabalhadores os respaldam e os apoiam, porque estes gângsteres ou estas pessoas más sempre têm estado respaldadas por grupos importantes de trabalhadores. Somente quando conseguimos nos adonar da consciência da massa e lhes fizemos notar que seus líderes são maus, temos obtido a (sua) expulsão... (Segovia, 1986: 255)

A imagem de austeridade de Fidel, portanto, responde basicamente a imperativos estratégicos. A honestidade pessoal não é avaliada como um valor absoluto, ficando em segundo lugar com relação ao respaldo da liderança por sua base. Essa valorização da lealdade combina bem com outro traço marcante da sua atuação: ausência de qualquer confrontação aberta com o presidente da República, seja qual for a política perseguida por este. Evidentemente, essa postura encobre divergências e conflitos de alta intensidade, e certamente mais de um primeiro mandatário tentou eliminar Fidel do comando do sindicalismo mexicano (Prieto, 1980: 100-101). A recusa em admiti-lo publicamente e a postura de lealdade constante foram, entretanto, fundamentais para a longa sobrevivência política de Velázquez, para quem, de acordo com o doutor em direito Alberto Trueba Urbina, citado por Prieto, "o único presidente importante [era] o presidente de turno" (Prieto, 1980: 76).

Embora o poder da CTM tenha feito do seu secretário-geral um dos participantes do ritual mais secreto da política mexicana - o "dedaço" no qual se define o candidato do PRI às eleições seguintes -, o fato de ele ter descartado a pretensão a ocupar a presidência da República, ou a exercer algum tipo de tutela sobre esta, era fundamental para afastar qualquer lembrança de personagens como Morones, Calles ou Obregón, representantes da fase "pré-institucional" da Revolução.

Já de Vicente Lombardo Toledano, Velázquez incorporou as bases de um discurso classista articulado com a valorização da especificidade da Revolu- 
ção Mexicana, que foi fundamental inicialmente na articulação do amplo arco de alianças políticas presentes à fundação da CTM e que, posteriormente, passou a justificar a colaboração com o Estado como melhor via para a defesa dos interesses dos trabalhadores. Toledano deixou como herança à CTM e a Velázquez um discurso que legitimava essa atitude colaboracionista em termos familiares às tradições políticas da esquerda, como pode ser percebido no pronunciamento do primeiro na abertura do Décimo Conselho Nacional Ordinário da CTM, em 12 de julho de 1939:

No caso particular do México, a intervenção da classe operária organizada na política não só é útil, mas é forçosa, porque o governo do México, desde 1910, é um governo militante, que trabalha a serviço das massas pobres de nosso país. Não é um governo neutro o governo do México: é um governo que trata de construir um México melhor, liberando as classes exploradas. (Prieto, 1980: 167)

Ao assumir o comando da CTM, Fidel operava sobre a base desses e de outros elementos discursivos e mecanismos de poder originalmente formulados por Toledano. Em sua atuação e no seu discurso, porém, o "lobinho pródigo" distanciou-se cautelosamente do intelectualismo, do esquerdismo e das influências internacionais que se tornaram associadas à figura do "licenciado" que o antecedeu.

Middlebrook define Fidel Velázquez como um "nacionalista conservador" que se empenhou ao longo da vida na realização das "metas igualitárias da Revolução", embora sempre dentro dos limites da estrutura institucional de poder dela resultante, numa atuação marcada pelo anticomunismo (Middlebrook, 1995: 112). Esse último aspecto, entretanto, pode ser relativizado. Quando Fidel assumiu a Secretaria-Geral da CTM pela primeira vez, a "unidade nacional" era encarnada pela aliança entre PRM e PCM, estando os militantes de ambos ainda presentes na CTM. Nos discursos proferidos nesse período, o inimigo identificado por Fidel era, via de regra, "a reação", encarnada no contexto mexicano pelos sinarquistas (movimento fascista), pelo Partido de Ação Nacional (PAN) e pela Igreja Católica (Segovia, 1986: 37, 127). ${ }^{7}$

Na leitura de Velázquez e seus companheiros sobre a história do México pós-revolucionário, Nação, Estado e partido oficial se apresentam amalgamados, e sua aliança com a classe operária teria sido consumada em dois momentos mitológicos: o "pacto secreto" da CROM com Obregón e a convocação de Cárdenas à unidade operária na luta contra Calles (Segovia, 1986: 28-29; Middlebrook, 1995: 387). A colaboração com o Estado estaria associada à responsabilidade dos 


\section{Alexandre Fortes}

trabalhadores organizados para com o país e a Revolução, e a CTM teria "boas relações com os regimes da Revolução" porque entenderia melhor do que outras correntes sindicais "a política do México" e estaria em melhores condições de "de cooperar, de acrescentar" (Prieto, 1980: 57-58).

Da defesa da Revolução Mexicana deriva uma postura de combate aos comunistas que se fundamenta mais na ênfase na particularidade da experiência nacional do que na divergência estritamente ideológica. Fidel destacava não ser comunista, porque a Revolução Mexicana teria provado "ser mais eficaz" e teria "alcançado maiores realizações que outros regimes no mundo". Apesar de não ser "uma revolução socialista ou coisa que lhe pareça", teria sido uma "revolução popular" (Prieto, 1980: 52). Ainda assim, em 1941, Velázquez afirmaria admirar os comunistas: "porque são revolucionários como eu e como todos nós, membros da CTM" (Segovia, 1986: 5). Anos depois, aumentaria suas críticas a eles, pelo fato de crerem que no México se poderiam "estabelecer as mesmas táticas e estratégias que se utilizam em qualquer outro país capitalista" (Velasco, 1986: 12).

Velázquez declarava, porém, que os sindicalistas da CTM não viam os comunistas mexicanos como "inimigos ideológicos". Ele reivindicava inclusive que seus companheiros teriam tido a capacidade de interpretar melhor as "teorias marxistas", as quais ele, numa entrevista à revista Excelsior, publicada em $1^{\circ} \mathrm{de}$ abril de 1983, dizia ter "lido muito". Destacava que "Carlos Marx deixou escrito para sempre um modo de viver para a humanidade", mas que suas ideias teriam que ser adaptadas "de acordo com a idiossincrasia do nosso povo" (Velasco, 1986: 43; González, 1991: 148). Entretanto, em discurso ao VII Congresso da CTM, pronunciado em 17 de abril de 1962, denunciava o "comunismo que se traduz em opressão, em assassinatos, em matança de massas, em falta de liberdade" (González, 1991: 147). Outro elemento que embasava o combate de Velázquez a comunistas e socialistas está associado à crítica de qualquer intervenção de forças políticas internacionais (leia-se URSS, China e Cuba) nos assuntos mexicanos (González, 1991: 145-146). Numa entrevista dada nos anos 1970, ironiza o anticomunismo fervoroso de Amilpa lembrando os discursos feitos por este anualmente na década de 1930 na data do aniversário de Stálin. Por outro lado, não fazia segredo do fato de que sua primeira gestão na Secretaria-Geral se dedicou a "limpar o terreno" da influência comunista na CTM (Segovia, 1986: 256).

Mas num ponto importante, ao menos, o discurso de Fidel se aproxima mais dos comunistas do que de uma perspectiva nacionalista tradicional, pois ele admitia a existência no país de uma "luta de classes que não foi inventada por ninguém, e que é uma consequência da divisão de classes gerada pelo capital" (Velasco, 1986: 43). A própria aliança com o Estado, na perspectiva de Fidel, se justifica entre outros motivos pela necessidade de enfrentar um empresariado intrinsecamente reacionário e intransigente (Segovia, 1986: 95). Ao ser inaugu- 
rada uma estátua em sua homenagem no centro de Monterrey, o sindicalista comentou: “(...) é uma honra para mim, que numa cidade eminentemente reacionária e capitalista se levante uma estátua em minha honra, já que a classe empresarial de Monterrey terá que sofrer ao ver-me presente por lá todos os dias" (González, 1991: 201).

Esse discurso classista poderia ser considerado contraditório com sua atitude nas diversas ocasiões em que o sindicalista assumiu uma posição contrária a movimentos de enfrentamento com o capital. Porém, mesmo a renúncia unilateral ao uso da greve, aprovada pela CTM na conjuntura da Segunda Guerra Mundial, foi efetuada como uma concessão circunstancial, sem abrir mão da legitimidade do direito e lembrando que a atitude "exige reciprocidade da parte dos patrões" (Segovia, 1986: 43). É bem verdade que o próprio programa do PRI defende o direito de greve "sem qualquer limitação", desde que se sigam "os caminhos da lei", o que evidentemente significa uma contradição em termos (Prieto, 1980: 173-174).

Já na greve dos trabalhadores do seguro social em 1947, Velázquez fazia uma distinção entre a justiça das reivindicações e a legitimidade do movimento, de um lado, e a avaliação dos interesses do governo em evitar a greve, que apontavam para um alto risco de fracasso, de outro (Segovia, 1986: 217-218). Para o sindicalista o uso da greve não se constituía em questão de princípio, pois entendia que "nem o aumento de greves nem a sua redução indica nada a respeito da força do movimento operário" (Prieto, 1980: 58).

A defesa dos interesses da classe trabalhadora contra o empresariado continuava como uma referência fundamental do discurso de Velázquez ainda em 1976, quando ensaiava uma autocrítica à situação da CTM e convocava os membros da central a uma "retificação":

Tampouco estamos convencidos de que todos os líderes operários sejam responsáveis, obrem com limpeza e retidão, nem de que todos os líderes sigam as diretivas da CTM e se empenhem em fortalecer suas organizações. Reclamamos uma maior ação, uma maior consciência classista, e que lutem com denodo e obtenham maiores resultados e que enfrentem com decisão à classe patronal, pois há quem se ponha de acordo com os patrões e burle os trabalhadores quando estes exigem o que lhes corresponde. (Prieto, 1980: 87)

Mas o que o personagem Fidel Velázquez pode nos dizer sobre o lugar do movimento operário no México pós-revolucionário? Por um lado, a construção da sua liderança austera, disciplinada e pragmática - tomada aqui como exemplo su- 


\section{Alexandre Fortes}

premo de uma concepção sindical professada por inúmeros sindicalistas pós-revolucionários mexicanos - limitou as possibilidades de sucesso de qualquer impulso de renovação mais significativa do movimento operário daquele país latino-americano. Desse modo, contribuiu para conter a dinâmica, potencialmente perigosa para o sistema político, de manifestações mais autônomas da classe trabalhadora. Por outro lado, o sucesso obtido por esses sindicalistas na ocupação de espaços institucionais fez com que a "classe política" e o empresariado mexicanos se vissem obrigados a conviver com, e em certa medida reverenciar, a memória viva de um processo que incorporou as massas trabalhadoras à política nacional e abriu as perspectivas para o vislumbrar de direitos sociais efetivos.

\section{Conclusão}

Em trabalho anterior, analisamos as significativas diferenças existentes entre diversos sindicalistas que atuaram em Porto Alegre entre os anos 1930 e o golpe de 1954 e foram, ao menos em algum momento, classificados como "pelegos" por seus adversários de esquerda. ${ }^{8}$ Demonstramos como as concepções expressas por esses sindicalistas, na verdade, eram muito variadas. Em um extremo, podemos encontrar uma visão do sindicato como uma extensão do aparelho de Estado no provimento de benefícios e serviços sociais, com absoluta dependência em relação ao seu poder normativo e repressivo. No outro, uma atitude crítica diante do corporativismo estatal que, entretanto, não impedia a exploração de todos os potenciais nele presentes para a atração das massas para o espaço sindical.

O deslocamento do foco para o exame da expressão máxima do pragmatismo sindical mexicano nos remete a um cenário radicalmente distinto. Embora seja possível identificar em Fidel Velázquez traços dos exemplos brasileiros mencionados acima, lidamos aqui com um personagem que, a partir da fragilidade estrutural das categorias com menor poder de barganha sindical, construiu um império capaz de responder à disponibilidade da elite política do México revolucionário por uma aliança estável e controlada com representações da classe trabalhadora urbana. Apesar das fortes semelhanças no plano da engenharia institucional corporativista adotada na regulamentação das relações de trabalho e da prática sindical nos dois países, é evidente que a possibilidade de atuação política dos sindicalistas, mesmo no campo oficialista, foi muito mais limitada no Brasil, como fica claro pela própria proibição da constituição de centrais sindicais. Além disso, Velázquez teve a possibilidade de estudar os perfis de atuação de líderes sindicais que obtiveram projeção nacional anteriormente, integrando como ponto forte da sua persona pública o discurso de incorporação dos trabalhadores ao processo revolucionário mexicano, enquanto afastava de si 
qualquer traço de ambição pessoal, intelectualismo e internacionalismo.

Não se trata aqui, evidentemente, de atribuir valor nominal aos discursos e declarações de Velázquez. Há sempre uma grande distância entre o discurso e a prática, embora não haja a princípio razões para presumir que no caso desse sindicalista essa distância seja maior do que no de qualquer outro. Ele, como líder nacional de grande porte, certamente tinha à sua disposição excelentes redatores, provavelmente de formação esquerdista. Mas o exame de seus discursos, depoimentos e pronunciamentos publicados, falas deliberadamente elaboradas para atingir grandes audiências, ajuda a explicitar o modo como esse ator, que cumpriu um papel fundamental para dar vida ao sistema corporativista de relações de trabalho do seu país, buscava legitimar a sua prática sindical e política, provavelmente remetendo a valores compartilhados por amplas parcelas da classe trabalhadora mexicana.

Esperamos que a análise aqui desenvolvida contribua para demonstrar, ainda que de forma preliminar, o quanto o estabelecimento de bases para um exercício comparativo com foco nos processos de construção de concepções e práticas sindicais pode ajudar a enriquecer a compreensão de alguns dos principais problemas da história política e social latino-americana no século XX.

Notas

1. Não há espaço aqui para tratar do debate sobre o uso do conceito de "populismo" na América Latina. Nossa posição sobre o tema foi apresentada de forma mais sistemática em Fortes (2007).

2. Ver também: "Escritor afirma que sociedade secreta governou México por 70 anos". Disponível em: < http://noticias. uol.com.br/ultnot/2005/08/17/ult1817u367 6.jhtm > . Acesso em: 17 de agosto de 2005.

3. "Biography and Political Culture: Luis Napoleón Morones and the Mexican Revolution" (Gregory Crider, Wingate University) and "Vicente Lombardo Toledano: A Mirror of an Era?" (Daniela
Spenser, CIESAS, MEXICO), ambos no painel "Biography and Mexican History".

4. Para um exemplo, ver Munakata (1981). Para uma crítica dessas abordagens, ver French (1991).

5. Verbete “Fidel Velázquez Sánchez, Mexican labour leader", Britannica Online Encyclopedia.

6. O papel da política de "unidade nacional" na primeira gestão de Velázquez pode ser avaliado a partir da análise de seus discursos, compilados em Segovia (1986: 27-135).

7. É interessante notar, contudo, que o anticlericalismo, característico do discurso político da Revolução Me- xicana, voltará a 
ser acionado por Fidel nos anos 1970, desta vez contra a atuação do clero "progressista" (Prieto, 1980: 186-188).

\section{Referências bibliográficas}

COSTA, Hélio da. Em busca da memória. São Paulo: Scritta, 1995.

FORTES, Alexandre. Nós do quarto distrito: a classe trabalhadora porto-alegrense e a era Vargas. Rio de Janeiro: Garamond Universitária; Caxias do Sul: Educs, 2004.

. O Estado Novo e os trabalhadores: a construção de um corporativismo latinoamericano. Locus, Juiz de Fora, vol. 13, 2007.

FORTES, Alexandre \& FERREIRA, Marieta de Moraes (org.). Muitos caminhos, uma estrela. Memórias de militantes do PT. São Paulo: Fundação Perseu Abramo, 2008.

FRENCH, John D. The Origin of Corporatist State Intervention in Brazilian Industrial Relations, 1930-1934: A Critique of the Literature. Luso-Brazilian Review, 1991.

. $O A B C$ dos operários: lutas e alianças de classe em São Paulo, 1900-1950. São Paulo: Hucitec, São Caetano do Sul: Prefeitura Municipal de São Caetano do Sul, 1995.

GAY, Luis \& TORRE, Juan Carlos. El Partido Laborista en la Argentina. Buenos Aires: Biblos/Fundación Simon Rodríguez, 1999.

GONZÁLEZ, Agustín Sánchez. Fidel, una historia de poder. México, D.F.: Planeta Mexicana, 1991.

HOROWITZ, Joel. The Impact of Pre1943 Labor Union Traditions on Pe-
8. Cf. o capítulo "Pelegos, pragmáticos, trabalhistas e comunistas", de Fortes (2004: 347-375). ronism. Fournal of Latin American Studies, vol. 15, n. 1, maio de 1983.

JAMES, Daniel. Resistance and Integration: Peronism and the Argentine Working Class, 1946-1976. Cambridge/New York: Cambridge University Press, 1988.

- Doña María's Story: Life History, Memory, and Political Identity. Durham (NC): Duke University Press, 2000.

LA BOTZ, Dan. Fidel Velazquez Sanchez: Embodiment of State-Unionism. Mexican Labor News and Analysis, 1997

LOBATO, Mirta Zaida. La vida en las fábricas: trabajo, protesta y política en una comunidad obrera, Berisso (1904-1970). Buenos Aires: Prometeo, 2001.

MATTOS, Marcelo Badaró. Novos e velhos sindicalismos: Rio de faneiro, 1955/1988. Rio de Janeiro: Vício de Leitura, 1998.

MIDDLEBROOK, Kevin J. The Paradox of Revolution: Labor, the State, and Authoritarianism in Mexico. Baltimore: Johns Hopkins University Press, 1995.

MUNAKATA, K. A legislação trabalhista no Brasil. São Paulo: Brasiliense, 1981.

NEGRO, Antonio Luigi. Linhas de montagem: o industrialismo nacional-desenvolvimentista e a sindicalização dos trabalhadores, 1945-1978. São Paulo: Fapesp/Boitempo, 2004.

PORTANTIERO, Juan Carlos \& MURMIS, Miguel. Estudios sobre los orígenes del 
peronismo. Buenos Aires: Siglo Veintiuno Argentina, 1971.

PRIETO, Jorge Mejía. El poder tras de las gafas. Hacia una análisis del cetemismo y Fidel Velázquez. México, D.F.: Diana, 1980.

REYES, Cipriano. Yo hice el 17 de octubre, 2 vols. Buenos Aires: GS, 1973.

SANTANA, Marco Aurélio. Homens partidos: comunistas e sindicatos no Brasil. Rio de Janeiro: UFRJ; São Paulo: Boitempo, 2001.

SEGOVIA, Eduardo (org.). Fidel Velázquez - Discursos. México, D.F.: Federación de Trabajadores de Nuevo Léon, 1986.

SILVA, Fernando Teixeira da. $A$ carga e a culpa. Os operários das docas de Santos: direitos e cultura de solidariedade, 1937-1968. São
Paulo: Hucitec; Santos: Prefeitura Municipal de Santos, 1995.

- Operários sem patrões: os trabalhadores da cidade de Santos no entre-guerras. Campinas: Unicamp, 2003.

TORRE, Juan Carlos. La vieja guardia sindical y Perón: sobre los orígenes del peronismo. Buenos Aires: Sudamericana/ Instituto Torcuato di Tella, 1990.

VELASCO, Carlos. Fidel Velázquez. México, D.F.: Plaza e Janes, 1986.

VELASCO PIÑA, Antonio. El círculo negro. El grupo detrás del poder en México. México, D.F.: Punto de Lectura, 2005.

Verbete "Fidel Velázquez Sánchez, Mexican labour leader". Britannica Online Encyclopedia.

\section{Resumo}

Tomando como objeto a trajetória de Fidel Velázquez Sanchez, líder supremo da Confederación de Trabajadores de México (CTM) por quase 60 anos, o artigo examina os modos como o foco em história oral, livros de memórias, biografias, assim como em discursos e declarações de sindicalistas contribui para tornar possível um novo olhar sobre a experiência dos trabalhadores sob regimes políticos latino-americanos tradicionalmente denominados "populistas".

Palavras-chave: sindicalismo, classe trabalhadora, México, populismo, corporativismo

\section{Abstract}

This article takes the story of Fidel Velázquez Sanchez, supreme leader of the Confederación de Trabajadores de México (CTM) for almost 60 years, to examine the ways in which the study of oral history, memoirs, biographies, as well as speeches and statements made by unionists contributes to make possible a new look at the experiences of workers under Latin American political regimes traditionally labeled as "populists".

Key words: unionism, working class, Mexico, populism, corporatism 


\section{Résumé}

En partant de l'histoire de Fidel Velázquez Sanchez, chef suprême de la Confederación de Trabajadores de México (CTM) pendant presque 60 ans, cet article examine les manières dont l'étude de l'histoire orale, des livres de mémoires, des biographies, ainsi que des discours et déclarations de syndicalistes contribue à rendre possible un nouveau regard sur l'expérience des travailleurs sous des régimes politiques latino-américains traditionnellement appelés "populistes".

Mots-clés: syndicalisme, classe travailleuse, Mexique, populisme, corporatisme 